\title{
Efficacy and Selectivity of Pre- and Post-emergence Herbicides in Chia (Salvia hispanica L.) under Mediterranean Semi-arid Conditions
}

\author{
Anestis C. KARKANIS ${ }^{1 *}$, Charis-Konstantina KONTOPOULOU ${ }^{2}$, \\ Christos LYKAS ${ }^{1}$, Ioanna KAKABOUKI ${ }^{2}$, Spyridon A. PETROPOULOS ${ }^{1}$, \\ Dimitrios BILALIS ${ }^{2}$
}

\author{
${ }^{1}$ University of Thessaly, Department of Agriculture Crop Production and Rural Environment, Fytokou St., 38446, Volos, \\ Greece; anekark80@yahoo.gr(*correspondingauthor); chlikas@uth.gr;fangio57gr@gmail.com \\ ${ }^{2}$ Agricultural University of Athens, Department of Crop Science, Iera Odos 75, 11855 Athens, \\ Greece; xariskon@gmail.com; i.kakabouki@yahoo.gr; bilalisdimitrios@yahoo.gr
}

\begin{abstract}
In the present study, the selectivity and efficacy of several post and pre-emergence herbicides in chia (Salvia hispanica L.) were examined. Field experiments were conducted at two locations with different soil types and environmental conditions. Our results showed that the pre-emergence application of pendimethalin, oxyfluorfen and linuron reduced total weed density by $71-74 \%, 74-82 \%$ and $53-55 \%$, respectively. Despite their high effectiveness against specific weed species, the abovementioned herbicides had a negative effect on plant density and biomass yield. In addition, herbicides bentazon and fluazifopp-butyl which applied post-emergence did not affect significantly plant height and biomass yield. In conclusion, the herbicides linuron, pendimethalin and oyxfluorfen do not seem to be a viable option for weed control in chia crop, whereas the postemergence applied herbicides did not affect significantly plants' growth. Further evaluation of chia tolerance to herbicides is needed under different application rates in order to make safe suggestions for chemical control of weeds.
\end{abstract}

Keywords: biomass yield, herbicides selectivity, phytotoxicity, soil types, weed control

\section{Introduction}

Chia (Salvia hispanica L.) is a member of the Lamiaceae family, with Mesoamerica and Western Mexico being recognized as its center of genetic diversity (Cahill, 2004). Salvia hispanica is a diploid species with $2 n=12$ chromosomes, which is the lowest chromosomes number among the species of Salvia genus (Estilai et al., 1990). It is an annual herb with opposite leaves which is usually cultivated for its nutritious seeds (Ali et al., 2012; Jamboonsri et al., 2012; Porras-Loaiza et al., 2014) and aromatic leaves (Ahmed et al., 1994). In Europe, "chia seeds" are considered as a new food ingredient (Commission Implementing Decision 2013/50/EU). Chia is also cultivated as a forage crop, producing high-quality fodder (Peiretti and Gai, 2009; Bilalis et al., 2016).

Chia seeds have a high nutritional value due to their high protein (18.5-22.3\%), fat (21.5-32.7\%) and fiber content (20.1-36.1\%) (Porras-Loaiza et al., 2014), while the main protein fractions of seeds are globulins (52-64.86\%) and glutelins (20.21\%) (Sandoval-Oliveros and ParedesLópez, 2013; Vázquez-Ovando et al., 2010). Chia seed oil is also rich in omega-3 and omega- 6 fatty acids, since it contains a high percentage of a-linolenic acid (59.9-63.2\%) and linoleic acid (20\%) (Ali et al., 2012; Álvarez-Chávez et al., 2008; Ayerza and Coates, 2011; Porras-Loaiza et al., 2014). Moreover, omega-3/omega-6 fatty acid ratio is 3:1 and therefore considered of high nutritional value (Guil $e t$ al., 1996; Porras-Loaiza et al., 2014). In 2009, the European Commission authorized the use of chia seeds in bread products with a maximum content of $5 \%$ (Commission Decision 2009/827/EC). Tartary buckwheat (Fagopyrum tataricum (L.) Gaertn.) and chia seeds flours can be used as combined ingredients in gluten-free breads (Costantini et al., 2014), since chia seeds do not contain gluten (Bueno et al., 2010). Seeds are also considered a good source of phytosterols (Álvarez-Chávez et al., 2008; Ciftci et al., 2012) and phenolic compounds (i.e. myricetin, quercetin, kaempferol, chlorogenic acid) (Marineli et al., 2014). Apart from seeds, leaves are used for aromatic and therapeutic purposes, with major essential oils compounds being $\beta$ - 
184

caryophyllene, globulol, $\gamma$-muurolene, $\beta$-pinene, $\alpha$ humulene, germacrene-B, and widdrol (Ahmed et al., 1994). According to Amato et al. (2015), chia leaves are a rich source of several flavonoids (i.e. acetyl vitexin, acetyl orientin, apigenin and luteolin glycosides).

Although chia shows a high potential as an alternative crop in many countries throughout the world (PorrasLoaiza et al., 2014), little information is available about its cultivation practices in Europe. Chia is sown directly in soil at a rate of $5-6 \mathrm{~kg} \mathrm{ha}^{-1}$ in rows $70-80 \mathrm{~cm}$ apart (Coates and Ayerza, 1996; Ayerza and Coates, 2009; Ayerza, 2010). So far, commercial cultivation takes place mainly in South America, where in Argentina, Coates and Ayerza (1996) reported that seed yield of chia varied between $175 \mathrm{~kg} \mathrm{ha}^{-1}$ and $918 \mathrm{~kg} \mathrm{ha}^{-1}$. However, in southern Europe, flowering of plants within mid-to-late autumn is a major drawback, especially when crop intended for seed production, since plants are susceptible to low temperatures. According to Jamboonsri et al. (2012), domesticated chia lines have photoperiod requirements for floral induction of about 12 $\mathrm{h}$; therefore in the northern hemisphere, plants begin to flower during October.

Another limiting factor for commercial cultivation of chia is weed interference, since weeds can severely affect both yield and quality of the final product. Cultivation and hand hoeing are still the main weed control practices. However, chemical control of weeds could be a useful means for commercial cultivation of chia, since usually hand hoeing is not practicable due to high cost and limited availability of labour. On other crops belonging to Lamiaceae family, several herbicides have been registered as safe for weed control. According to Schmatz et al. (2009) the herbicides bentazon, fluazifop-p-butyl, pyridate and clopyralid can be safely used in peppermint (Mentha $\times$ piperita). In another study, oxyfluorfen applied at a rate of $0.20 \mathrm{~kg} \mathrm{ha}^{-1}$ prior to emergence increased Japanese mint (Mentha arvensis L.) herb yield (Kaur et al., 2013), while Singh and Saini (2008) observed that diuron applied at a rate of $0.6 \mathrm{~kg} \mathrm{ha}^{-1}$ was safe for weed control in Japanese mint crop. To our knowledge, there are no registered herbicides for chemical control of broad-leaved or grass weeds in chia crop, in European Union. Therefore, the aim of this study was to evaluate the efficacy and selectivity of pre- and postemergence herbicides in chia crop. The experiment were carried out at two locations with different soil types and climate conditions in order to assess different scenarios of growing conditions.

\section{Materials and Methods}

\section{Experimental site}

Chia crop was established at two locations in Central Greece: a) at the experimental field of the University of Thessaly in Velestino, Thessaly Region (22.756E, 39.396N; Site 1), where soil was sandy clay loam (38\% sand, $36 \%$ silt, and $26 \%$ clay) with $\mathrm{pH} 7.4\left(1: 1 \mathrm{soil} / \mathrm{H}_{2} \mathrm{O}\right)$, and $\left.\mathrm{b}\right)$ at the province of Domokos in Central Greece (22.336E, $39.036 \mathrm{~N}$; Site 2 ), where soil was clay ( $50.7 \%$ clay, $23.3 \%$ silt, and $26 \%$ sand) with $\mathrm{pH} 7.6\left(1: 1 \mathrm{soil} / \mathrm{H}_{2} \mathrm{O}\right)$. Meteorological data of both experimental sites are presented in Fig. 1. Seeds were sown on May $5^{\text {th }}, 2014$ and May $10^{\text {th }}, 2014$, at site 1 and 2, respectively. Seedbeds were prepared with moldboard plough to a depth of $25-30 \mathrm{~cm}$, followed twice by a rotary tiller to a depth of $15 \mathrm{~cm}$. Seeds were sown by hand in rows $60 \mathrm{~cm}$ apart and a depth of $1 \mathrm{~cm}$.

\section{Experimental design}

The experimental design was a randomized complete block design with three replicates per treatment for both sites. The experiments were set up over an area of $163 \mathrm{~m}^{2}$ $(21.75 \times 7.5 \mathrm{~m})$ at each location, with plots of $2 \mathrm{~m}$ wide and $3 \mathrm{~m}$ long, while the corridors between plots were $0.75 \mathrm{~m}$ wide. A range of herbicides available for use on Lamiaceae species was selected. The treatments were randomized within the blocks and were as follows: bentazon $(1.2 \mathrm{~kg}$ a.i. ha $^{-1}$; Basagran $\left.48 \mathrm{SL}\right)$, fluazifop-p-butyl $\left(0.25 \mathrm{~kg}\right.$ a.i. ha ${ }^{-1}$; Fusilade $12.5 \mathrm{EC})$, linuron (0.9 kg a.i. $\mathrm{ha}^{-1}$; Afalon 47.5 WP), pendimethalin (1.137 kg a.i. ha ${ }^{-1}$; Stomp Aqua 455 CS), oxyfluorfen (0.6 kg a.i. ha-1 Goal $48 \mathrm{SC}$ ), and control treatment (no herbicides; weeds were controlled by hand hoeing at 60 days after sowing (DAS)).

Pendimethalin, oxyfluorfen, and linuron were applied pre-emergence. After the application of these herbicides and for incorporation purposes, experimental plots were irrigated using a sprinkler irrigation system. In addition, bentazon and fluazifop-p-butyl were applied when chia plants reached the 6-8 true leaf stage. Herbicides were applied with a field plot sprayer, with constant pressure at $250 \mathrm{kPa}$, using a total water volume of $300 \mathrm{~L} \mathrm{ha}^{-1}$. At both sites, after weed assessment (60 DAS), all the experimental plots were kept weed free by hand hoeing until final harvest. At 30 DAS, ammonium nitrate (34.5-0-0) was applied at a rate of $200 \mathrm{~kg} \mathrm{ha}^{-1}$, while irrigation was applied when needed.

\section{Sampling, measurements and methods}

To determine the effect of selected herbicides on plants growth, the density of the emerged plants was recorded at 21 days after sowing (DAS), while plant height and dry weight were determined throughout the growing period (at $36,50,64$ and $82 \mathrm{DAS})$. Photosynthetic rate $\left(\mu \mathrm{mol} \mathrm{CO}_{2}\right.$ $\mathrm{m}^{-2} \mathrm{~s}^{-1}$ ) and stomatal conductance ( $\mathrm{mol} \mathrm{H}_{2} \mathrm{O} \mathrm{m}^{-2} \mathrm{~s}^{-1}$ ) measurements took place at 10:30 am to $2: 30$ pm under clear sky, at 36 and 50 DAS, on the $2^{\text {nd }}$ pair of fully expanded leaves from the apex, using a LCi Leaf Chamber Analysis System (ADC, Bioscientific, Hoddesdon, UK), with three measurements per plot. For plant height and dry weight determination, 5 plants were randomly selected from each plot.

At both locations, chia plants flowered at the beginning of October; however, although plants produced seeds the crop was damaged by frost prior to seed maturity, therefore seed yield was not determined. Furthermore, at 60 DAS, the number and dry weight of the main weeds were assessed. For weed assessments, a wooden square quadrate $(0.40 \mathrm{~m} \times$ $0.40 \mathrm{~m}$ ) was placed twice in each plot. The dry weight was determined after drying at $60{ }^{\circ} \mathrm{C}$ to a constant weight. Weed density and biomass were expressed as number $\mathrm{m}^{-2}$ and $\mathrm{g} \mathrm{m}^{-2}$, respectively.

\section{Statistical analysis}

The data were subjected to analysis of variance and the means were compared using Fisher's Least Significant Difference $(L S D)$ test $(P<0.05)$. These analyses are 

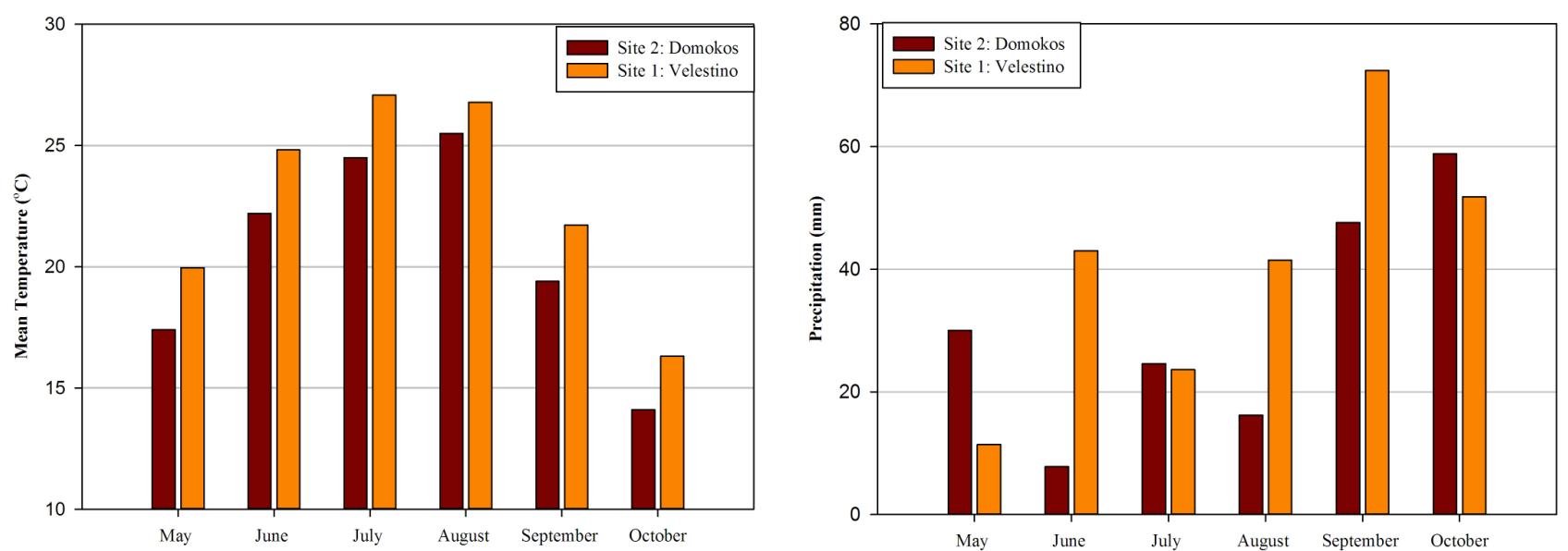

Fig. 1. Meteorological data at experimental sites (Velestino, Domokos) in Greece, during the growing season (May to October 2014)

Table 1. Results of two-way analysis of variance (ANOVA) for effects of herbicide $(\mathrm{H})$ and experimental site $(\mathrm{S})$ on plant height $(\mathrm{PH})$, dry weight (DW), photosynthetic rate (A) and stomatal conductance ( $\mathrm{gs}$ ) at 36, 50, 64 and 82 days after sowing

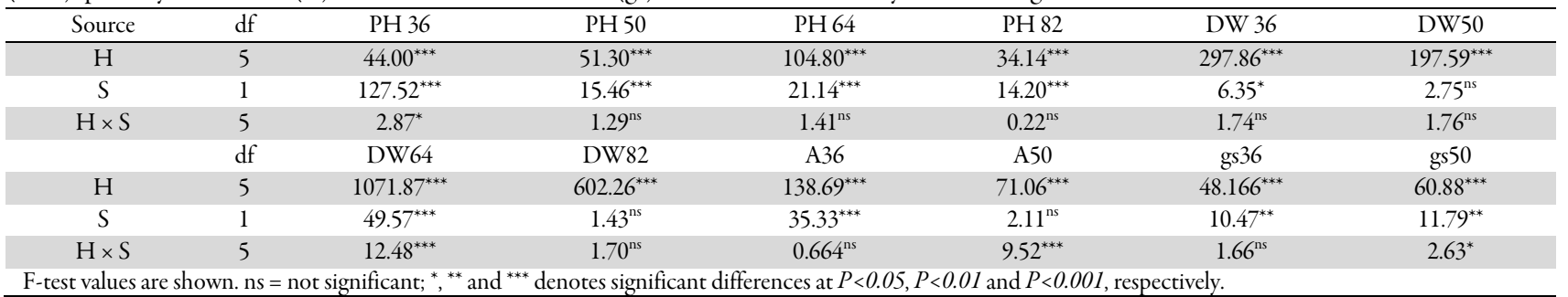

presented in Table 1 , while the data are presented in figures as means of three replicates. Pearson's correlation analysis was also performed to examine the relationships between chia traits. All statistical analyses were carried out with SigmaPlot software package, version 12 (Systat Software Inc., San Jose, CA).

\section{Results}

\section{Weed flora}

At site 1, the main weeds were Convolvulus arvensis L., Portulaca oleracea L., Solanum nigrum L. and Sorghum halepense (L.) Pers., while at site 2, the main weeds were $C$. arvensis, $P$. oleracea, $S$. nigrum, Hibiscus trionum L. and Echinochloa crus-galli (L.) P. Beauv. Regarding the total weed density and biomass yield, there were significant differences between herbicides treatments (Fig. 2). The lowest weed density and biomass were observed in oxyfluorfen plots, followed by pendimethalin application. Oxyfluorfen had the best performance for $P$. oleracea control, pendimethalin provided more than $85 \%$ control of $S$. nigrum and E. crus-galli, while fluazifop-p-butyl resulted in more than $65 \%$ and $90 \%$ control of $S$. halepense and $E$. crus-galli, respectively. Bentazon was also found to be the less effective herbicide against $S$. nigrum and $P$. oleracea (data not shown).

\section{Chia growth and biomass yield}

Regarding the chia seedlings emergence, there were significant differences between treatments $(\mathrm{F}=4.284$,
$P<0.05)$. At both sites, chia seedlings emergence was suppressed by linuron, pendimethalin and oxyfluorfen. At site 1, pendimethalin, linuron and oxyfluorfen reduced the chia emergence by $56 \%, 41 \%$ and $81 \%$, respectively, while at site 2, the application of pendimethalin, linuron and oxyfluorfen resulted in a reduction of chia emergence by $55 \%, 34 \%$ and $75 \%$, respectively.

The pre-emergence herbicides had a negative effect on chia plants growth (Fig. 3), while oxyfluorfen caused substantial crop injury (i.e. leaf necrosis and limited root system). At the first measurement, the lowest height of plants (7 and $6 \mathrm{~cm}$, at site 2 and site 1, respectively) was recorded for oxyfluorfen treatment, while the highest height was recorded for control plots $(21$ and $18 \mathrm{~cm}$, at site 2 and site 1, respectively). At this growth stage, chia height was reduced by $67 \%, 42 \%$ and $48 \%$ in oxyfluorfen, linuron and pendimethalin plots, respectively.

The effect of pre-emergence herbicides on chia growth resulted in a significant reduction in biomass yield compared to control treatment, while significant differences were also observed between herbicide treatments. At 36 DAS, the lowest dry weight was recorded for oxyfluorfen treatment (16.63 kg ha ${ }^{-1}$ and $18.68 \mathrm{~kg} \mathrm{ha}^{-1}$ at site 2 and site 1 , respectively), while the highest chia biomass was recorded for control plots (Fig. 4). A positive and significant correlation was also observed between biomass and crop density $(\mathrm{r}=0.924, P<0.001)$. The post-emergence herbicides (bentazon and fluazifop-p-butyl) did not affect chia growth. Slight necrosis of leaves was observed on some plants after spraying with bentazon. However, the symptoms were 
transient and disappeared within 2-3 weeks. Moreover, no significant differences were observed between bentazon, fluazifop-p-butyl and control treatment concerning the height and dry weight of chia plants at 36 and 50 DAS (Figs. 3 and 4). At 64 DAS, bentazon reduced significantly dry weight in comparison to the fluazifop-p-butyl and control treatments at site 1 . Moreover, at 82 DAS, there were no significant differences between bentazon, fluazifop-p-butyl and control concerning biomass yield of chia crop (Fig. 6).

Regarding the stomatal conductance and photosynthetic rate of chia plants, there were significant

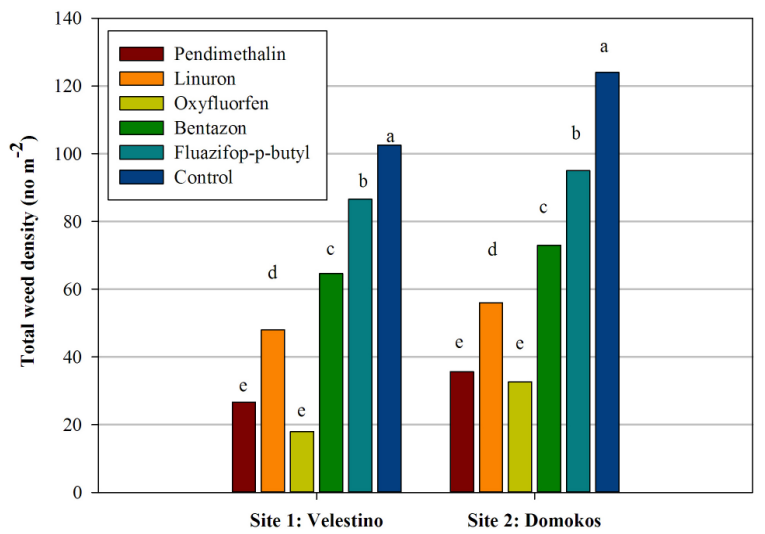

differences between herbicide treatments. At 36 DAS, photosynthetic rate of chia plants was reduced by $59-62 \%$, $42-48 \%$ and $43-45 \%$ in oxyfluorfen, linuron and pendimethalin plots, respectively. These results are in accordance with the above-mentioned dry weight reduction caused by oxyfluorfen, linuron and pendimethalin application. However, there were no statistically significant differences between bentazon, fluazifop-p-butyl and control treatments concerning the stomatal conductance and photosynthetic rate of chia plants (Fig. 5).

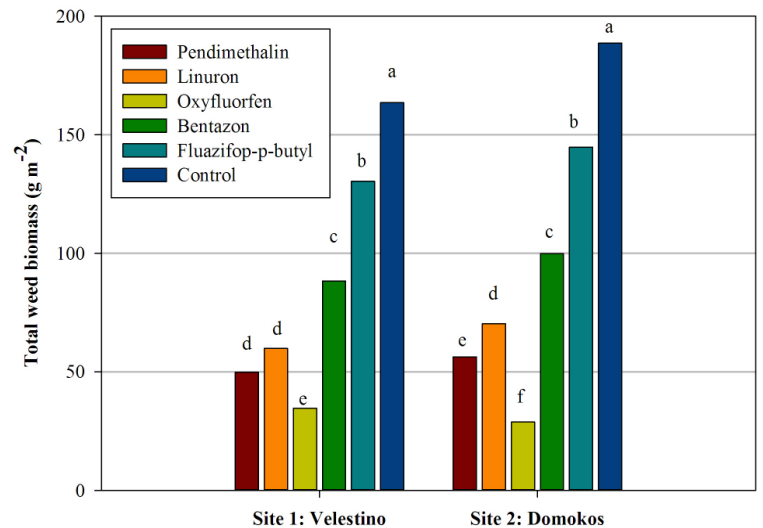

Fig. 2. Total weed density $\left(\right.$ no $\left.\mathrm{m}^{-2}\right)$ and biomass $\left(\mathrm{g} \mathrm{m}^{-2}\right)$ in chia crop as affected by the herbicide treatments at the experimental sites: Velestino (site 1) and Domokos (site 2). At each site, bars followed by different letters indicate significant differences according to Fisher's Least Significant Difference (LSD) test $(P<0.05)$
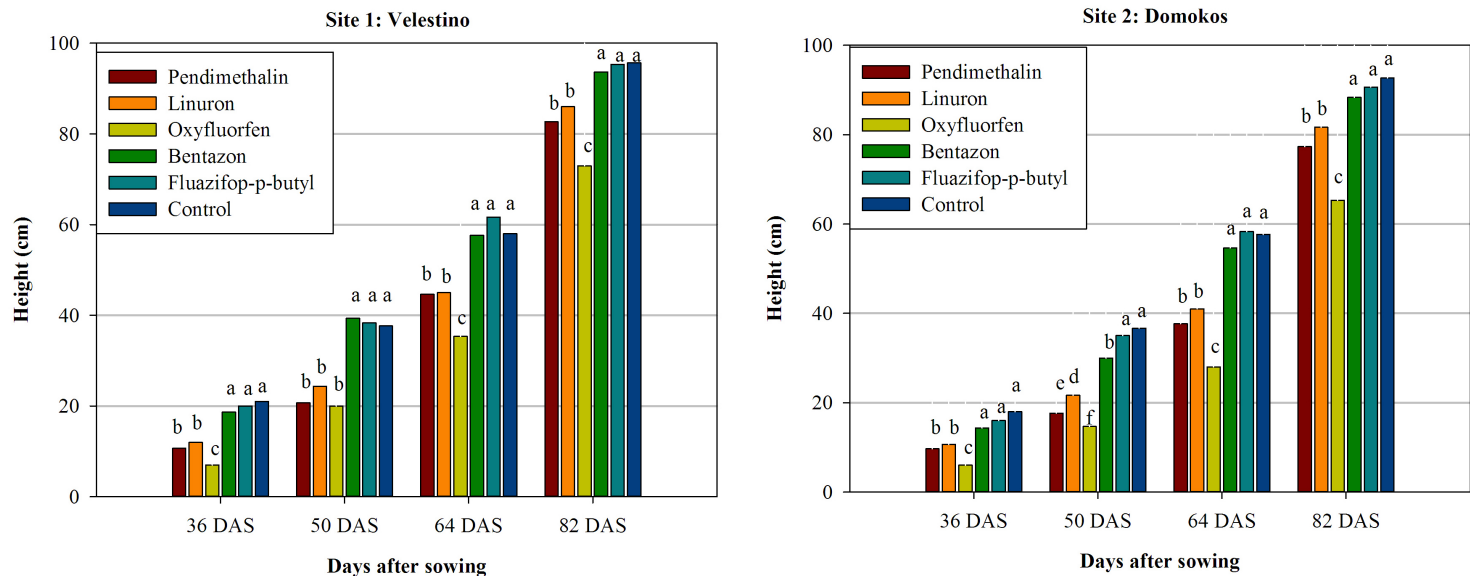

Fig. 3. Effects of herbicide treatments on plant height $(\mathrm{cm})$ at 36, 50, 64 and 82 days after sowing (DAS) at the experimental sites: Velestino (site 1) and Domokos (site 2). At each measurement, means followed by the same letter are not significantly different according to Fisher's Least Significant Difference $(L S D)$ test $(P<0.05)$.
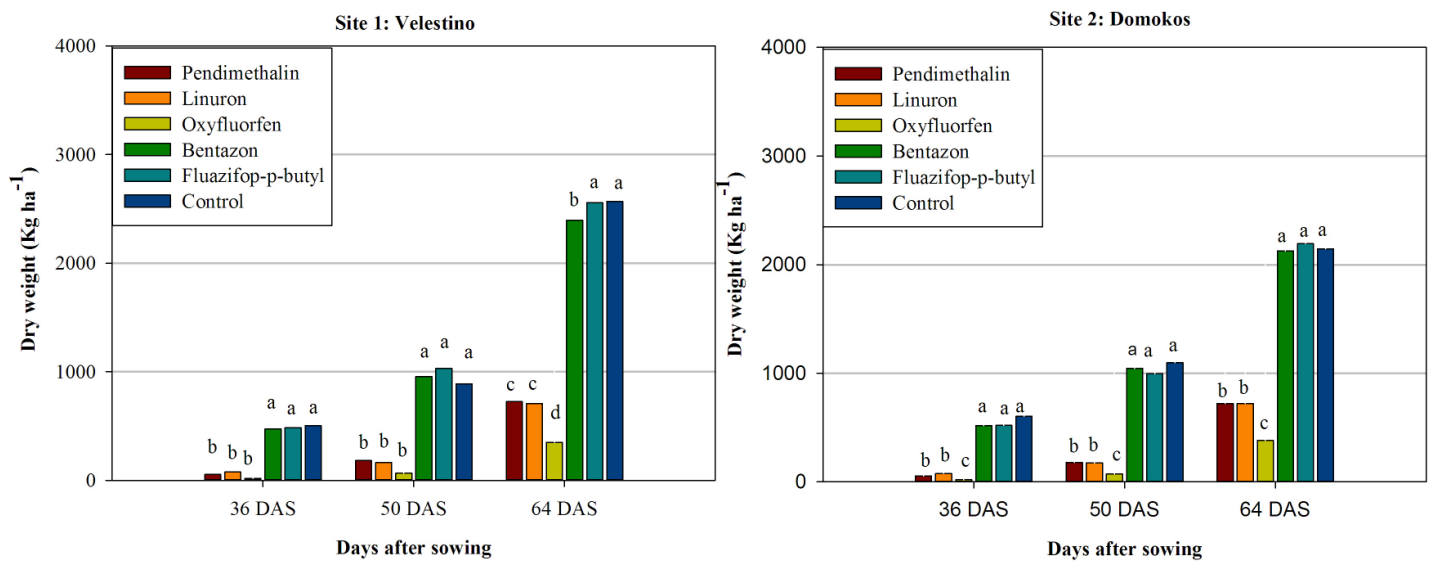

Fig. 4. Effects of herbicide treatments on dry weight $\left(\mathrm{kg} \mathrm{ha}^{-1}\right)$ of chia crop at 36,50 and 64 days after sowing (DAS) at the experimental sites: Velestino (site 1) and Domokos (site 2). At each measurement, means followed by the same letter are not significantly different according to Fisher's Least Significant Difference $(L S D)$ test $(P<0.05)$ 

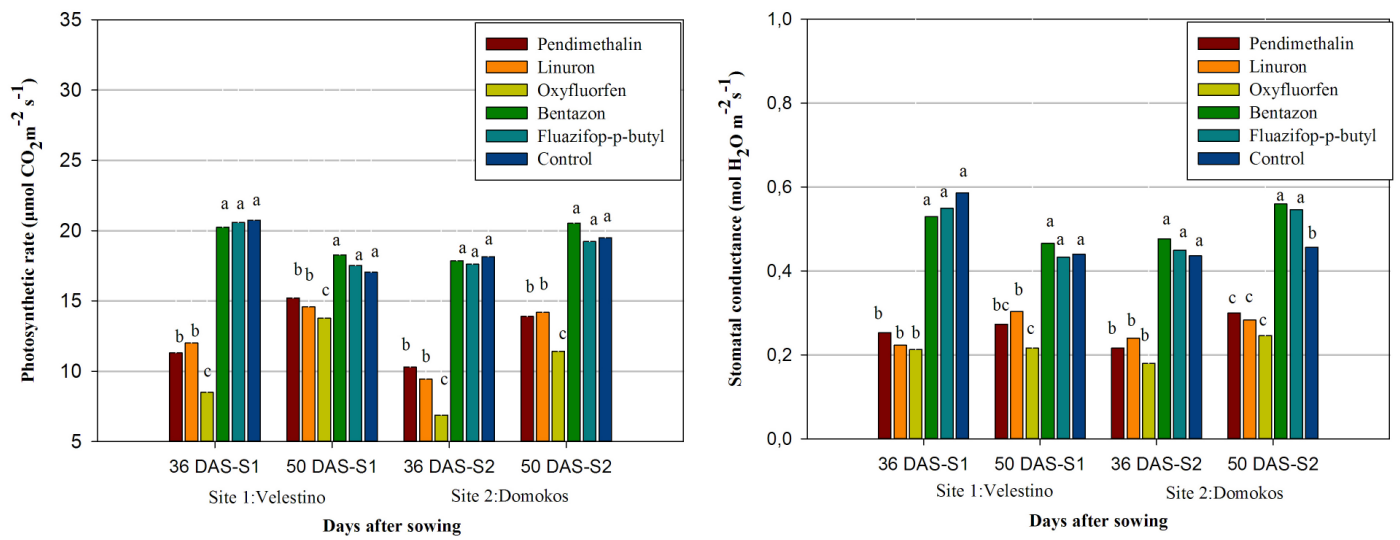

Fig. 5. Effects of herbicide treatments on a) photosynthetic rate $\left(\mu \mathrm{mol} \mathrm{CO} \mathrm{Cm}^{-2} \mathrm{~s}^{-1}\right)$ and b) stomatal conductance $\left(\mathrm{mol} \mathrm{H}_{2} 0 \mathrm{~m}^{-2} \mathrm{~s}^{-1}\right)$ of chia plants at 36 and 50 days after sowing (DAS) at the experimental sites: Velestino (site 1) and Domokos (site 2). At each measurement, means followed by the same letter are not significantly different according to Fisher's Least Significant Difference $(L S D)$ test $(P<0.05)$

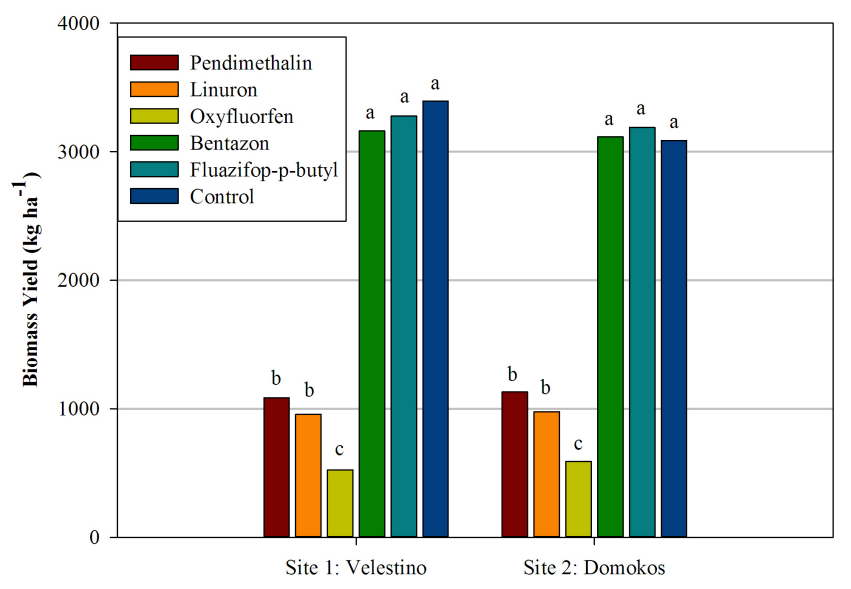

Fig. 6. Effects of herbicide treatments on biomass yield ( $\mathrm{kg}$ $\mathrm{ha}^{-1}$ ) of chia crop, at 82 days after sowing (DAS) at the experimental sites: Velestino (site 1) and Domokos (site 2). Means followed by the same letter are not significantly different according to Fisher's Least Significant Difference $(L S D)$ test $(P<0.05)$

\section{Discussion}

The results of the present study indicated that maximum weed density reduction was observed from oxyfluorfen followed by pendimethalin treatment. Oxyfluorfen application resulted in efficient control of almost all broad-leaved weeds (i.e. S. nigrum and $P$. oleracea), while pendimethalin provided more than $85 \%$ control of $S$. nigrum and E. crus-galli. Similar levels of weed control efficacy for pendimethalin and oxyfluorfen have been previously reported by Karkanis et al. (2012). Bentazon was found to be the less effective herbicide against annual broad-leaved weeds. Villegas Rojas (2012) also found that the post-emergence application of bentazon provided poor weed control in chia crop.

The post-emergence herbicides bentazon and fluazifopp-butyl did not affect significantly the growth of chia plants. Foliar injury was observed only in bentazon plots, which was not reflected in biomass yield. In a recent study, Villegas Rojas (2012) have also reported that bentazon and quizalofop-p-ethyl caused foliar injury in chia crop (i.e. chlorosis and apical meristem necrosis). In addition, the preemergence herbicides had a negative effect on chia plants growth. At both sites, chia seedlings emergence was suppressed by linuron, pendimethalin and oxyfluorfen. Similarly, Villegas Rojas (2012) reported that the application of trifluralin, metolachlor, linuron and pendimethalin reduced chia seedlings emergence. However, the suppression of seedlings emergence by linuron and oxyfluorfen was greater at site 1 than that at site 2, indicating a significant effect of soil types on herbicide selectivity. However, the main reason for lower phytotoxicity of the above-mentioned herbicides at site 2 may be attributed to soil physical properties, since the soil at this site was heavier than that at site 1. According to Rahman et al. (2011) the level of phytotoxicity of soilapplied herbicides varies between different soils types. In particular, herbicide injury in field crops is more likely to occur on light textured soils with low clay content. In a recent study, Jones et al. (2013) reported that hybrid bermudagrass $[C$. dactylon (L.) pers. $\times C$. transvaalensis Burtt-Davy] injury by indaziflam was greater in sandy soil than in silt loam soil. Therefore, the fact that the soil at site 2 contained more clay than site 1 , may contributed to the reduction of linuron and oxyfluorfen phytotoxicity. In contrast, there was no significant difference on chia seedlings emergence in plots treated with pendimethalin at both fields, probably due to the capsule suspension formulation of pendimethalin that was being used. The controlled release of the active ingredient from microcapsules resulted in a similar effect on seedlings emergence at both sites.

Biomass yield was also decreased significantly by the preemergence application of herbicides. The lowest chia biomass was recorded for oxyfluorfen, while the greatest biomass was found in control plots. In a recent study, Serreau and Raimondo (2015) also observed that the preemergence application of flurochloridone, diflufenican and linuron caused slight crop injury which ranged from 10 to $15 \%$, while sulfetrazone caused severe injury (up to $50 \%$ ) to chia plants. According to James et al. (1991), linuron at 1.5 
188

$\mathrm{kg}$ a.i ha ${ }^{-1}$ and prometryn at $0.5 \mathrm{~kg}$ a.i ha ${ }^{-1}$ applied preemergence resulted in a $7-43 \%$ damage to sage (Salvia officinalis L.), while linuron at $1 \mathrm{~kg}$ a.i ha $\mathrm{a}^{-1}$ and prometryn at $0.5 \mathrm{~kg}$ a.i ha ${ }^{-1}$ resulted in a $7-17 \%$ damage of clary sage plants (Salvia sclarea L.). In contrast, Mitchell et al. (1995) reported that linuron at $0.75 \mathrm{~kg}$ a.i ha ${ }^{-1}$ and pendimethalin at $1.5 \mathrm{~kg}$ a.i ha ${ }^{-1}$ were well tolerated by transplanted plants of sage.

The lowest photosynthetic rate of chia plants was recorded for pre-emergence herbicides. At early growth stages, the limited root system of plants in oxyfluorfen and pendimethalin treated plots may contributed significantly to higher reduction of stomatal conductance and photosynthetic rate of these plants, comparing to the other treatments.

The main reason for the observed differences between the tested herbicides may be attributed to their different persistence in soil. The dissipation of linuron and pendimethalin in soil is faster than that of oxyfluorfen. According to Triantafyllidis et al. (2012), the half-life of pendimethalin in loam soil ranged between 26.7 and 27.5 days. Under different environmental and soil conditions, Tsiropoulos and Lolas (2004) observed that the half-life of the same herbicide ranged between 43 and 62 days. In addition, the dissipation rates also depend on soil properties. According to Swarcewicz et al. (2013), the half-life of linuron in sandy loam and clay loam soils was 37 days and 44 days, respectively. Furthermore, oxyfluorfen is more persistent in soil than pendimethalin, regardless of soil type. In particular, Alister et al. (2009) observed that the half-life of pendimethalin ranged between 10.5 and 31.5 days, while the half-life values of oxyfluorfen, in the same soil, ranged between 34.3 and 52.3 days.

\section{Conclusions}

Our results indicate that the application of preemergence herbicides pendimethalin, linuron and oxyfluorfen, at the tested rates, affects significantly plants' growth and seedlings emergence. Among the tested herbicides, oxyfluorfen caused the most severe damage in chia crop. In addition, oxyfluorfen was more efficient against almost all broad-leaved weeds, while pendimethalin provided more than $85 \%$ control of Solanum nigrum and Echinochloa crus-galli. However, further studies have to be conducted to evaluate the selectivity of herbicides in chia crop under different application rates, soil types and environmental conditions in order to make safe suggestions for chemical control of weeds.

\section{References}

Ahmed M, Ting IP, Scora RW (1994). Leaf oil composition of Salvia hispanica L. from three geographical aress. Journal of Essential Oil Research 6:223-228.

Ali NM, Yeap SK, Ho WY, Beh BK, Tan SW, Tan SG (2012). The promisingfuture ofChia, Salvia hispanica L.Journal of Biomedicine and Biotechnology 171956.

Alister CA, Gomez PA, Rojas S, Kogan M (2009). Pendimethalin and oxyfluorfen degradation under two irrigation conditions over four years application. Journal of Environmental Science and Health, Part B 44:337-343.
Álvarez-Chávez LM, Valdivia-López MDLA, Aburto-Juárez MDL, Tecante A (2008). Chemical characterization of the lipid fraction of Mexican chia seed (Salvia hispanica L). International Journal of Food Properties 11:687-697.

Amato M, Caruso MC, Guzzo F, Galgano F, Commisso M, Bochicchio R, ... Favati $F(2015)$. Nutritional quality of seeds and leaf metabolites of chia (Salvia bispanica L.) from Southern Italy. European Food Research and Technology 241:615-625.

Ayerza R (2010). Effects of seed color and growing locations on fatty acid content and composition of two chia (Salvia hispanica $\mathrm{L}$ ) genotypes. Journal of American Oil Chemists' Society 87:1161-1165.

Ayerza R, Coates W (2009). Some quality components of four chia (Salvia bispanica L.) genotypes grown under tropical coastal desert ecosystem conditions. Asian Journal of Plant Sciences 8:301-307.

Ayerza R, Coates W (2011). Protein content, oil content and fatty acid profiles as potential criteria to determine the origin of commercially grown chia (Salvia hispanica L). Industrial Crops and Products 34:1366-1371.

Bilalis D, Tabaxi I, Zervas G, Tsiplakou E, Travlos I, Kakabouki I, Tsioros S (2016). Chia (Salvia hispanica) fodder yield and quality as affected by sowing rates and organic fertilization. Communications in Soil Science and Plant Analysis 47:17641770.

Bueno M, di Sapio O, Barolo M, Busilachi H, Quiroga M, Severin CY (2010). Quality tests of Salvia hispanica L. (Lamiaceae) fruits marketed in the city of Rosario (Santa Fe province, Argentina). Boletín Latinoamericano y del Caribe de Plantas Medicinales y Aromáticas 9:221-227.

Cahill PJ (2004). Genetic diversity among varieties of chia (Salvia bispanica L). Genetic Resources and Crop Evolution 51:773-781.

Ciftci ON, Przybylski R, Rudzińska M (2012). Lipid components of flax, perilla, and chia seeds. European Journal of Lipid Science and Technology 114:794800.

Coates W, Ayerza R (1996). Production potential of chia in northwestern Argentina. Industrial Crops and Products 5:229-233.

Commission Decision (2009/827/EC). Commission Decision of 13 October 2009 authorising the placing on the market of Chia seed (Salvia hispanica) as novel food ingredient under Regulation (EC) No 258/97 of the European Parliament and of the Council (notified under document C(2009) 7645). Official Journal of European Union L294:415.

Commission Implementing Decision (2013/50/EU). Commission Implementing Decision of 22 January 2013 authorising an extension of use of Chia (Salvia hispanica) seed as a novel food ingredient under Regulation (EC) No 258/97 of the European Parliament and of the Council (notified under document C(2013) 123). Official Journal of European Union L21:3435.

Costantini L, Lukšič L, Molinari R, Kreft I, Bonafaccia G, Manzi L, Merendino N (2014). Development of gluten-free bread using tartary buckwheat and chia flour rich in flavonoids and omega-3 fatty acids as ingredients. Food Chemistry 165:232-240.

Estilai A, Hashemi A, Truman K (1990). Chromosome number and meiotic behavior of cultivated chia, Salvia hispanica (Lamiaceae). HortScience 25:1646-1647. 
Guil JL, Torija ME, Giménez JJ, Rodriguez I (1996). Identification of fatty acids in edible wild plants by gas chromatography. Journal of Chromatography A 719:229-235.

Jamboonsri W, Phillips TD, Geneve RL, Cahill JP, Hildebrand DF (2012). Extending the range of an ancient crop, Salvia hispanica L-a new $\omega-3$ source. Genetic Resources and Crop Evolution 59:171-178.

James TK, Rahman A, Douglas JA (1991). Control of weeds in five herb crops. In: Proceedings of the $44^{\mathrm{th}} \mathrm{NZ}$ Weed Pest Control Conference pp 116-120.

Jones PA, Brosnan JT, Kopsell DA, Breeden GK (2013). Soil type and rooting depth affect hybrid Bermudagrass injury with preemergence herbicides. CropScience 53:660-665.

Karkanis A, Bilalis D, Efthimiadou A, Katsenios N (2012). Comparison between conventional and organic weed management: Growth and yield ofleek (Allium porrum L.).Horticultural Science 39:81-88.

Kaur T, Singh S, Bhullar MS, Shergill LS, Kaur R (2013). Effect of planting methods and weed control on productivity of Japanese mint (Mentha arvensis L.). Indian Journal of Agricultural Research 47:243-247.

Marineli RDS, Moraes TA, Lenquiste SA, Godoy AT, Eberlin MN, Maróstica JrMR (2014). Chemical characterization and antioxidant potential of Chilean chia seeds and oil (Salvia hispanica L.). LWT Food Science and Technology 59:13041310.

Mitchell RB, Abernethy RJ, McGimpseyJA (1995). Herbicide tolerance of transplanted Dalmatian sage and oregano. In: Proceedings of the $48^{\text {th }}$ NZPlant Protection Conferencepp 327-330.

Peiretti PG, Gai F (2009). Fatty acid and nutritive quality of chia (Salvia bispanica L.) seeds and plant during growth. Animal Feed Science and Technology 148:267-275.

Porras-Loaiza P, Jiménez-Munguía MT, Sosa-Morales ME, Palou E, LópezMalo A (2014). Physical properties, chemical characterization and fatty acid composition of Mexican chia (Salvia hispanica L.) seeds. International Journal of Food Science and Technology 49:571-577.

Rahman A, James TK, Trolove MR, Dowsett C (2011). Factors affecting the persistence of some residual herbicides in maize silage fields. New Zealand Plant Protection 64:125-132.
Sandoval-Oliveros MR, Paredes-López O (2013). Isolation and characterization of proteins from chia seeds (Salvia hispanica L.). Journal of Agricultural and Food Chemistry61(1):193-201.

Schmatz R, Schäkel C, Dick C (2009). Herbicide tests in peppermint (Mentha $\times$ piperita L.) in Thuringia. GesundePflanzen 61:1-10.

Serreau WRJ, Raimondo JG (2015). Evaluación de herbicidas preemergentes en chía (Salvia hispánica L.) en Tucumán (Argentina): control de malezas y fitotoxicidad. XXII Congreso de la ALAM I Congreso de la ASACIM, Malezas 2015.9 y 10 de Septiembre, Bueno Aires, Argentina. MM.EP.35.

Singh MK, Saini SS (2008). Planting date, mulch, and herbicide rate effects on the growth, yield, and physicochemical properties of menthol mint (Mentha arvensis). Weed Technology22:691-698.

Swarcewicz M, Gregorczyk A, Sobczak J (2013). Comparison of linuron degradation in the presence of pesticide mixtures in soil under laboratory conditions. Environmental Monitoring Assessment 185:8109-8114.

Triantafyllidis V, Hela D, Papadaki M, Bilalis D, Konstantinou I (2012). Evaluation of mobility and dissipation of mefenoxam and pendimethalin by application of CSTR model and field experiments using bare and tobacco tilled soil columns. Water Air \& Soil Pollution 223:1625-1637.

Tsiropoulos NG, Lolas PC (2004). Persistence of pendimethalin in cotton fields under sprinkler or drip irrigation in central Greece. International Journal of Environmental Analytical Chemistry 84:199-205.

Vázquez-Ovando JA, Rosado-Rubio JG, Chel-Guerrero LA, BetancurAncona DA (2010). Dry processing of chia (Salvia hispanica L.) flour: Chemical characterization of fiber and protein. CyTA-Journal of Food 8:117-127.

Villegas Rojas D (2012). Efecto de la aplicación de herbicidas sobre el rendimiento en Chía (Salvia bispanica L.) en la región Metropolitana. Resumen de memoria para optar al título profesional de ingeniero agrónomo. Universidad de Chile, Facultad de Ciencias Agronómicas, Departamento de Producción Agrícola. Retrieved 2017 April 30 from http://www.chia.uchile.d/docs/estudios/Diane\%20Villegas.pdf. 